\title{
The status of soil erosion in the Upper Blue Nile Basin: Identification of hot spot Areas and Evaluation of Best Management Practices in the Toba Watershed
}

\author{
Wakjira Takala Dibaba ( $\nabla$ wak.nimona@gmail.com ) \\ Jimma University Institute of Technology https://orcid.org/0000-0002-9359-2142 \\ Dessalegn Geleta Ebsa \\ Jimma University Institute of Technology
}

\section{Research Article}

Keywords: BMP, sediment yield, Toba watershed

Posted Date: September 3rd, 2021

DOl: https://doi.org/10.21203/rs.3.rs-868407/v1

License: (c) (1) This work is licensed under a Creative Commons Attribution 4.0 International License.

Read Full License 
1 The status of soil erosion in the Upper Blue Nile Basin:

2 Identification of hot spot Areas and Evaluation of Best

$6{ }^{1}$ Department of Hydraulic and Water Resources Engineering, Jimma Institute of

$8 \quad{ }^{1}$ Department of Water supply and Environmental Engineering, Jimma Institute of 
13 Land degradation caused by soil erosion has become the most serious problem in the

14 Ethiopian highlands. Quantifying the spatial variations of soil loss with a strong evidence helps to prioritize the watersheds for the implementation of different management practices. The study was carried out in the Toba Watershed of the Upper Blue Nile Basin in Ethiopia. Its objective was to evaluate the rate of soil erosion and identify the hotspots with high risk of soil erosion for watershed management planning. Then, Soil and Water Assessment Tool (SWAT) was used to evaluate the effectiveness of best management practices (BMP) in reducing soil loss. The performance of SWAT in simulating streamflow and sediment yield was evaluated through sensitivity analysis, uncertainty, calibration and validation process. Statistically, the calibrated and validated sediment yields (SY) against the observed sediment data were reasonably accurate $\left(\mathrm{R}^{2}=0.67,0.65, \mathrm{NSE}=0.66,0.64, \mathrm{PBIAS}=-8.4 \%, 9.8 \%\right.$ respectively $)$. The annual $\mathrm{SY}$ in Toba watershed varies from $0.09 \mathrm{tha}^{-1} \mathrm{yr}^{-1}$ to $44.8 \mathrm{tha}^{-1} \mathrm{yr}^{-1}$ with an average SY of 22.7 $\mathrm{tha}^{-1} \mathrm{yr}^{-1}$. To prioritize the SY of the watershed, the annual severity of SY was divided into six classes: very low, low, moderate, high, very high and severe. The study also showed that SY in most watersheds (about 53.8\%) were higher than the average. Cultivation on steep slopes leads to the highest SY, while forested areas have lower SY contribution. five management scenarios were evaluated using the Calibrated model. Seventeen sub-basins with SY exceeding the tolerable erosion of Ethiopia $\left(\mathrm{t} \mathrm{ha}^{-1} \mathrm{yr}^{-1}\right)$ were considered for the analysis of the BMP scenario. The results show that reforestation combined with vegetative strips was the most effective for soil erosion control ( $87.8 \%$ reduction) followed by the combination of soil/stone bund and vegetative strips ( $83.7 \%$ reduction). Overall, the results of this study provided important data for watershed management and are very useful to ensure the sustainable management of land and natural resources at watershed level.

Keywords: BMP; sediment yield; Toba watershed

\section{Introduction}

\subsection{General Background}

41 Regardless of the endowed diverse natural resources, Ethiopia is experiencing severe 
land and environmental degradation that has been a serious causes of low productivity resulting in a widespread poverty and food insecurity. Agricultural productivity in Ethiopian highlands are highly affected by pervasive land degradations [1-3]. Land degradation due to soil erosion in the highlands are due to the intermingling factors like lack of effective watershed management practices, increased agricultural activities on steep slopes, land use/land cover change, heavy rainfall, climate variability and mixed crop-livestock farming systems [4,5].

In Ethiopia, severe soil erosion risks are strongly linked with population density [3]. Expansion of agricultural lands, urban development and expansion and the need of extracting timber and other products to meet the needs of an increasing population is accelerating the degradations of natural resource and the environment. Soil erosion by water is the dominant forms of the degradations. This is a particular problem in Upper Blue Nile, the source of Nile River due to the higher erosion rate potentials [6]. According Haregeweyn et al. [3], about 39\% of the upper Blue Nile basin is subject to severe and very severe ( $>30 \mathrm{t}$ ha-1yr-1) soil erosion which could potentially threatens reservoirs in the downstream including Grand Ethiopian Renaissance Dam. Moreover, excessive soil loss is posing severe challenges to the productivity of land and rural developments, operation and function of water infrastructure, products and services of livelihoods. The effect is a great challenge to the farming system, decreasing profitability of farmers, income and employment [7] adding extra risk to a social, economic and environmental problems.

In addition to the on-site effects of soil erosion, there are off-site effects. Soil erosion poses significant impact on the sustainability of the reservoirs and irrigation projects in 

degradation reduces the life span of hydraulic structures increasing the vulnerability of the structures to siltation and scoring. The loss of vegetation and the consequent soil erosion causes dam to fill up with sediment more quickly, resulting in poor energy production. Sediment accumulation hampers proper operation of dams and also causes reservoirs to submerge more area resulting in loss of land use, biodiversity and social

71 impact. The recurrent power-cuts of electric power distribution recently experienced in Ethiopia are partially attributed due to the loss of storage capacity of hydroelectric power reservoirs which is a consequence of sedimentation. In order to increase the life

74 of the reservoir and to best achieve the purpose for which it has been constructed, 75 reducing sediment inflow is very important. To this end, reducing sediment and nutrient 76 inflow through different management approaches is of paramount importance [8]. Moreover, the application of effective and sustainable watershed management practices could enable to increase the life span of the reservoirs in the downstream and enhances the ecosystems services provided by terrestrial and other aquatic ecosystems (wetlands,

80 river and streams).

81 Cognizant of the evidences that Ethiopia has suffered a lot from natural resources

82 degradation, the problem has urged the government to affirm a commitment to address 83 land degradation through different policies. Example: Community-based Participatory 84 Watershed Development (CPWD) [9] and Sustainable Land Management (SLM) 85 Programs $[1,10]$. However, the evidences on the extents of the management initiatives 86 for the activities of the conservation is not clear. Moreover, the undertakings and 87 investments to combat the problems are still lower and the magnitude of the degradation 
exceeds the management/conservation activities by far and soil erosion continued to be

89 the major problem. Soil and water conservation is not supported by prioritizing 90 appropriate interventions suspectable and erosion prone areas. This, therefore, implies

91 that interventions to address the existing threats of soil degradations and thereby 92 enhance the socio-economic and ecological resilience of the watershed that involves 93 multidimensional and multi-sectorial approach is required.

94 Usually, identifying sediment sources and prioritizations of hot spot areas to soil 95 erosion is required for a proper watershed management as resources (human, 96 technological and financial) are limited [11-13]. In this regard, estimations of the soil 97 loss and identifying different management practices that suits the agroecology of a 98 particular study is required $[8,14]$. There are two approaches for estimation of soil loss: $99 \mathrm{plot} /$ field based $[6,15,16]$ and watershed based techniques $[11,12,17,18]$. However, 100 research experiences showed that watershed-based approach is more effective than the 101 plot-based technique for the management of soil degradation.

102 The application of agricultural and structural based management practices called Best 103 Management practices (BMPs) are preferred to manage soil loss from critical areas $104[13,19]$. The selection of best management practices that helps to reduce soil erosion 105 and sediment loss requires a systematic research that allows to assess the effectiveness 106 of the practices. A physical and process-based model, Soil and Water Assessment Tool 107 (SWAT) was used to estimate the risk of soil loss and evaluate the effectiveness of 108 BMPs to curb the soil erosion risks and sediment loss in Toba watershed where soil 109 erosion is rampant. The SWAT model was used based on its strong capability in 110 identifying the most critical areas and spatial variability of sediment yield with in the 
111 watershed. The model also allows the use of the combined factors like land use/land

112 cover, soil, climate, steepness of slope and simulation of different soil and water

113 management scenarios.

114 Prioritization BMPs that can reduce the risks of soil erosion and sediment loss is an

115 important contribution to decision makers, stake holders and practitioners because it

116 guides effective priorities in soil and water management. Therefore, the objective of

117 this study was to estimate the annual soil loss rate to identify erosion hot spot areas and

118 prioritize different BMPs to reduce the risk of soil erosion and sediment loss.

\section{2. Materials and Methods}

$120 \quad 2.1$ Study Area

121 Toba watershed is a tributary of Didessa sub-basin in the headwater of the Ethiopian

122 plateau, Upper Blue Nile Basin. Upper Blue Nile (named as Abbay in Ethiopia) is one

123 of the 12 river basins of Ethiopia (Figure 1, left hand side). Geographically, Toba

124 watershed is located between $36^{\circ} 2^{\prime} 50^{\prime \prime}$ to $36^{\circ} 37^{\prime} 5^{\prime \prime}$ East and $7^{\circ} 46^{\prime} 30^{\prime \prime}$ to $8^{\circ} 15^{\prime} 45^{\prime \prime}$ North

125 with an altitude range from 1425 to 2596 m.a.s.l (Figure 1, right hand side). The

126 drainage area of the watershed is $1828.4 \mathrm{~km}^{2}$. Agriculture is the dominant activity in

127 the watershed and forest and rangelands are the dominant cover. 


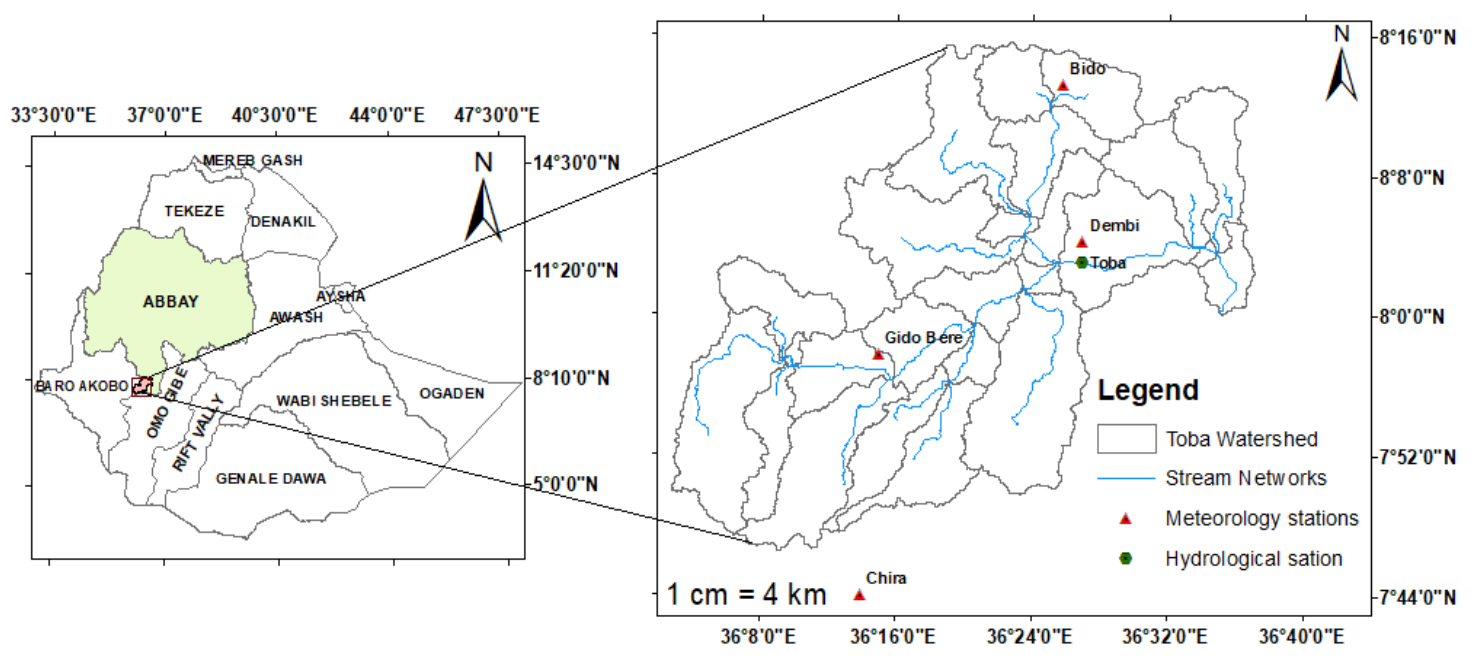

Figure 1: Map of the study area

130 The mean annual rainfall in the catchment varies from $1497 \mathrm{~mm}$ in the south western

131 and $2500 \mathrm{~mm}$ in the northeastern part of the watershed. The watershed is characterized

132 by humid tropical climate with heavy rainfall. The maximum and minimum

133 temperature in Toba ranges from 18 to $36^{\circ} \mathrm{C}$ and 6.5 to $17^{\circ} \mathrm{C}[20]$.

\section{$134 \quad 2.2$ Input Data}

135 The application of SWAT model to evaluate the spatial distribution of soil loss and 136 quantify effectiveness of the BMPs requires the integration of spatial and temporal data 137 with the application of different management practices. The spatial datasets used 138 include: Digital Elevation Model (DEM), land use/land cover and soil data (Table 1).

139 Whereas the temporal data includes weather data, streamflow and sediment data. The 140 significance of different management scenario was evaluated SWAT model to curb soil 141 loss. Digital Elevation Model (DEM), soil, land use/land cover, and weather data are 142 used to develop and configure the SWAT model. Streamflow and sediment data are used 143 to calibrate and validate the model.

144 Table 1. Description of spatial and temporal data used for SWAT modelling in Toba 145 Watershed modified from Dibaba et al. [17]. 


\begin{tabular}{|c|c|c|c|}
\hline Data Types & Description & Source & Period/Scale \\
\hline DEM & $\begin{array}{l}\text { DEM was used to delineate the } \\
\text { watershed, stream networks }\end{array}$ & $\begin{array}{c}\text { Shuttle Radar Topography } \\
\text { Mission (SRTM) } 1 \text { Arc-Second } \\
\text { Global from } \\
\text { https://earthexplorer.usgs.gov }\end{array}$ & $30 \mathrm{~m}$ \\
\hline $\begin{array}{l}\text { Land Use/ } \\
\text { land Cover }\end{array}$ & $\begin{array}{l}\text { Land use/land cover map of } 2019 \\
\text { was used to quantify the } \\
\text { hydrological process }\end{array}$ & $\begin{array}{l}\text { LULC map derived from Landsat } \\
8 \text { OLI }\end{array}$ & $30 \mathrm{~m}$ \\
\hline Soil & $\begin{array}{l}\text { Soil data from a vector map was } \\
\text { processed in to a } 30 \mathrm{~m} \text { raster to } \\
\text { match the spatial resolution of } \\
\text { other spatial data. World digital } \\
\text { soil map and soil grids were used } \\
\text { to extract the Soil physico- } \\
\text { chemical properties }\end{array}$ & $\begin{array}{l}\text { Soil data processed from Ministry } \\
\text { of Water, Irrigation and } \\
\text { Electricity with the World digital } \\
\text { soil map and digital soil map grids }\end{array}$ & $\begin{array}{l}1: 50,000 \text { and } \\
250 \mathrm{~m} \text { grid }\end{array}$ \\
\hline Weather & $\begin{array}{l}\text { Daily rainfall, temperature, wind } \\
\text { speed, relative humidity, solar } \\
\text { radiation of } 5 \text { stations were used } \\
\text { to derive the hydrological balance }\end{array}$ & $\begin{array}{l}\text { National Meteorological Agency, } \\
\text { Ethiopia (NMA) }\end{array}$ & $1988-2020$ \\
\hline Streamflow & $\begin{array}{l}\text { Daily stream flow data of Toba } \\
\text { station was used to calibrate and } \\
\text { validate streamflow }\end{array}$ & $\begin{array}{c}\text { Ministry of Water, Irrigation and } \\
\text { Electricity, Ethiopia }\end{array}$ & $2000-2015$ \\
\hline $\begin{array}{l}\text { Sediment } \\
\text { Data }\end{array}$ & $\begin{array}{l}\text { Suspended sediment data of Toba } \\
\text { stations used to calibrate and } \\
\text { validate sediment yield }\end{array}$ & $\begin{array}{l}\text { Ministry of Water, Irrigation and } \\
\text { Electricity, Ethiopia }\end{array}$ & $2000-2015$ \\
\hline
\end{tabular}

146 The spatial maps of the Toba watershed landscape attributes are presented in Figure 2.

147 Agriculture followed by Forest was the dominant land use/land cover in Toba watershed.

148 The dominant soil type in Toba watershed is Dystric Nitisols followed by Dystric

149 Gleysols (Figure 2). Elevation ranges of the watershed varies from $1425 \mathrm{~m}$ around the

150 outlet to $2596 \mathrm{~m}$ around the periphery of the watershed with majority of the watershed

151 characterized by elevation higher than $2100 \mathrm{~m}$. 

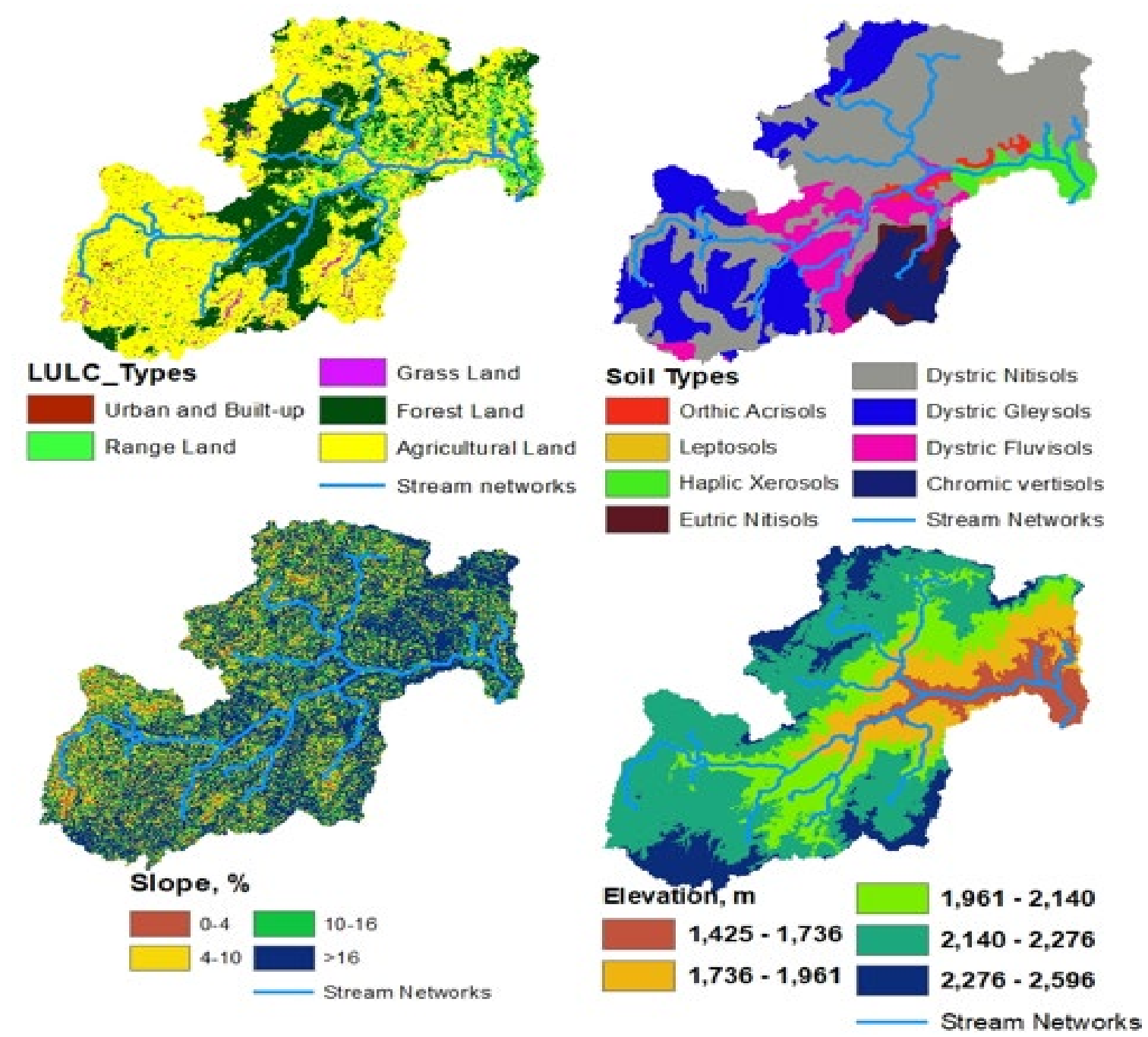

Figure 2. The spatial data attributes of Toba watershed: LULC, soil, slope and elevation

\section{$154 \quad 2.3$ Methodology}

\subsubsection{Soil and Water Assessment Tool Hydrological model}

156 SWAT is a watershed based, continuous-time and processed based model developed to

157 allow simulation of larger and complex watershed to predict the impact of land

158 management practices on water quality and quantity in agricultural watersheds over

159 long periods [21]. SWAT simulates watershed hydrology in two major phases: land

160 phase which controls the amount of water, sediment, nutrients and pesticides loading

161 to the main channel in each sub-basin and water or routing phase which controls the

162 movement of water, sediment and nutrients through channel network of the watershed 
163 to the outlet $[22,23]$. The hydrological simulation of SWAT based on the water balance 164 is given in $\mathrm{Eq}(1)$ below:

$$
\mathrm{SW} t=\mathrm{SW} o+\sum_{\mathrm{i}=1}^{\mathrm{t}}(\mathrm{Rday}-\mathrm{Q} s-\mathrm{E} a-\mathrm{Wseep}-\mathrm{Q} g w)
$$

Where: SW $t$ is the final soil water content $(\mathrm{mm}), \mathrm{SW} o$ is the initial water content $(\mathrm{mm})$,

$167 \mathrm{t}$ is the time (days), Rday is the amount of precipitation on the $\mathrm{i}$-th day $(\mathrm{mm}), \mathrm{Q} s$ is the 168 amount of surface runoff on day $\mathrm{i}(\mathrm{mm}), \mathrm{E} a$ is the amount of evapotranspiration on day

$169 \mathrm{i}(\mathrm{mm})$, Wseep is the amount of water entering the vadose zone in day $\mathrm{i}(\mathrm{mm}), \mathrm{Q} g w$ is 170 the amount of return flow on day $\mathrm{i}(\mathrm{mm})$.

171 SWAT simulates soil erosion due to rainfall and runoff based on the Modified 172 Universal Soil Loss Equation (MUSLE) using Eg (2) [24].

$173 S e d=11.8 \times\left(Q_{\text {surf }} x q_{\text {peak }} x \text { area }_{\text {hru }}\right)^{0.56} \times K_{\text {USLE }} \times C_{U S L E} \times P_{U S L E} \times L_{\text {USLE }} \times C F R G_{U S L E}(2)$

174 Where: Sed is the sediment yield from a given HRU on storm basis (ton/day), $Q_{\text {surf }}$ is 175 surface runoff volume $(\mathrm{mm} / \mathrm{ha}), q_{\text {peak }}$ is peak surface runoff $\left(\mathrm{m}^{3} / \mathrm{s}\right)$, area hru $_{\text {ru }}$ is the area 176 of hydrologic response unit (ha), $K_{U S L E}$ is the soil erodibility factor $\left(\mathrm{MgMJ}^{-1} \mathrm{~mm}^{-1}\right)$, $177 P_{U S L E}$ is soil erosion control protection factors, $L S_{U S L E}$ is topography factor, $C_{U S L E}$ is 178 crop management factor, $C F R G_{U S L E}$ is coarse fragment factor.

\section{$179 \quad$ 2.3.2 Sediment Rating Curve}

180 Sediment concentrations with the corresponding streamflow data at Toba gauging 181 station collected from Ministry of Water, Irrigation and Electricity are available only 182 for few months in a year. However, the application of SWAT hydrological model to 183 simulate streamflow and sediment yield requires a continuous time step of streamflow 184 and sediment data. Consequently, sediment rating curve was used to generate sediment 
185 load data from the streamflow using the empirical relations between the sediment 186 concentration and their corresponding streamflow. The use of estimates derived from 187 empirical relations between sediment concentrations and the corresponding river 188 discharge are used often when the long-term and reliable records of sediment 189 concentrations are limited [25].

190 The relationship between sediment concentrations and river discharge can be written 191 as:

$$
\mathrm{Qs}=\mathrm{a}^{*} \mathrm{Qf}^{\mathrm{b}}
$$

192 Where: Qs is the sediment load in ton/day, Qf is the streamflow in $\mathrm{m}^{3} / \mathrm{s}$, a and $\mathrm{b}$ are 193 regression constants to be determined from the suspended sediment loads and observed 194 streamflow. The sediment concentration record was measured in $\mathrm{mg} / \mathrm{l}$ and to work on 195 Eq (3), the sediment concentration was converted in to sediment load (ton/day) using 196 the following conversion formula (Equation 4).

$$
\mathrm{Qs}=0.0864 * \mathrm{C} * \mathrm{Qf}
$$

197 Where, $\mathrm{C}$ is sediment concentration $(\mathrm{mg} / \mathrm{l})$, Qf is the streamflow (m3/s) and 0.0864 is 198 the conversion factor. In Toba watershed, $\mathrm{a}$ and $\mathrm{b}$ are determined to be 6.8096 and 1.204 199 respectively. The sediment rating curve is shown by Figure 3. 


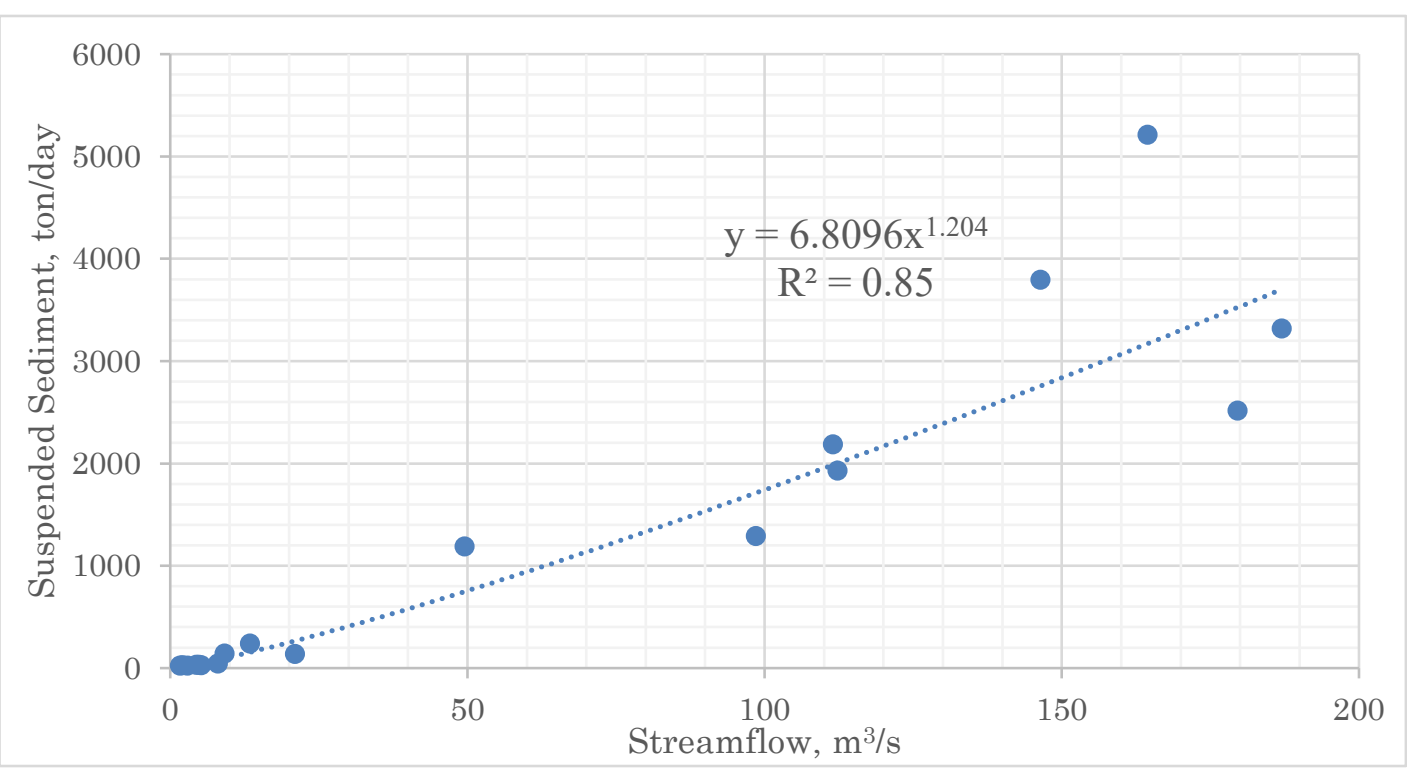

201 Figure 3. Sediment Rating Curve of Toba Watershed

\subsubsection{Best Management Practices}

203 Prior to the application of the BMPs, the SWAT model was calibrated and validated, 204 and the model was parameterized to evaluate the effects of the soil and water 205 management scenarios, which were then considered as the baseline scenario. The 206 selection of BMPs and their parameter values is specific to topography, land use/land cover, soil and agro-ecology and the selection should reflect the actual situation of the 208 study area [26]. Therefore, the purpose of the intervention, past experience and 209 recommendations provided in the Ethiopian Watershed Development Guidelines [9], 210 and Soil and water conservation development agents guide [27] were used to select 211 BMPs for the simulation in the SWAT model. Four BMPs applicable to the study area 212 includes; filter strip, soil/stone bund, vegetative strip, reforestation and their 213 combinations. These practices are largely under implementations in the Blue Nile basin.

214 a) Base line Scenario (BS): In the BS scenario, SWAT simulated the average sediment 215 yield based on the actual watershed conditions. 
216 b) Filter strip (FS): FS is used to reduce soil loss and its effect was simulated by 217 increasing the width of the filter strips (FILTERW) on croplands and pasture lands.

218 c) Soil/stone bund (SB): This approach is the most reasonable technique commonly 219 used in the Ethiopian highlands. SB reduces surface runoff and sediment loss by 220 reducing the slope length and creating retention areas [28]. In this study, the effects 221 of SB were simulated on steep slopes of the watershed by modifying the slope 222 length (SLSUBBSN), the slope (HRU_SLP), the curve number (CN2) and the 223 the use of physical structures like Terraces and Fanya Juu.

228 d) Vegetative strip(VS): VS are established along the contour lines of the farmlands 229

e) Reforestation (R): Reforestation on steep slopes and degraded land can help to increase soil cover, helping to ensure the soil and water conservation [12]. In this to reduce surface runoff and soil loss by reducing slope length and creating retention areas [12]. The effect of VS was simulated by modifying SLSUBBSN, HRU_SLP, USLE-P and FILTERW, as shown in Table 2. study, the reforestation of grasslands, shrublands and cropland that are on slopes greater than $16 \%$ was applied by introducing land use/land cover in the land use update of the watershed data. We considered this scenario to restore forests that have been destroyed. Converting all crop land to forest land is not feasible. In this regard, only $5 \%$ of the crop land was considered for reforestation. 
239 f) Combined Scenarios: Combined scenarios were evaluated based on the percent

240 change in the sediment yield reduction by combining the applications of two

241 scenarios. The application of Reforestation with vegetative strip, reforestation with

242 soil/stone bund and soil/stone bund with vegetative strip was applied to compare

243 the significance of the combined scenarios and the individual scenarios.

244 Table 2. Description of the BMPs scenarios and the parameter changes in the SWAT

\begin{tabular}{|l|l|l|l|}
\hline Scenario & Parameter & Pre-BMP/Calibrated & Post-BMP/ modified \\
\hline Baseline (BL) & - & - & - \\
\hline Filter Strip (FS) & FILTERW & 0 & 1 \\
\hline \multirow{5}{*}{ Soil/stone bund (SB) } & CN2.mgt & $*$ & $*-3$ \\
\cline { 2 - 5 } & USLE_P & 0.5 & 0.32 \\
\cline { 2 - 5 } & SLSUBBSN & $*$ & $0.50^{*}$ \\
\cline { 2 - 5 } & HRU_SLP & $*$ & $0.75^{*}$ \\
\hline \multirow{5}{*}{ Vegetative contour strips (VS) } & FILTERW & 0 & 1 \\
\cline { 2 - 5 } & USLE_P & 0.5 & 0.34 \\
\cline { 2 - 5 } & SLSUBBSN & $*$ & $0.50^{*}$ \\
\hline & HRU_SLP & $*$ & $0.75^{*}$ \\
\hline \multirow{5}{*}{ Reforestation (R) } & It is a management practice where croplands on hilly areas \\
\hline & were changed in to plantation forests with slope $>16 \%$ by $5 \%$ \\
\hline
\end{tabular}

$245 \quad *$ : calibrated values

\section{$246 \quad$ 2.3.4 SWAT model setup and uncertainty Analysis}

247 The SWAT model setup consists the following procedures: Preparation of spatial and

248 temporal data, watershed delineation and sub-basin discretization, HRU definition, 
writing weather inputs, and calibration and uncertainty analysis. A 30 by $30 \mathrm{~m}$ resolution

250 DEM was used to delineate the watershed. Then, HRU definition was held using a

251 threshold value of $15 \%, 10 \%, 10 \%$ for land use, soil and slope respectively. Toba

252 watershed was discretized into 25 sub-basin and 260 HRUs. Global sensitivity analysis

253 was performed both for streamflow and sediment to identify the most influencing

254 parameters. Then, SWAT model calibration and validation for stream flow and sediment

255 was done using SUFI-2 algorithms in SWAT-CUP for the periods of 2000-2006 and

256 2007-2012 respectively. The model performance was evaluated using Coefficient of

257 determination $\left(\mathrm{R}^{2}\right)$, Nash Sutcliff efficiency (NSE) and percent bias (PBIAS). These

258 statistics were calculated using the following equation.

259 A. Coefficient of determination, $\mathbf{R}^{2}$

260

$$
R^{2}=\frac{\sum_{i=1}^{n}[(Q o b s-Q \overline{o b s})(Q \operatorname{sim}-\bar{Q} \operatorname{sim})]^{2}}{\sqrt{\sum_{i=1}^{n}(Q o b s-Q o b s m)^{2} \sum_{i=1}^{n}(Q \operatorname{sim}-Q \operatorname{sim})^{2}}} ; 0 \leq R^{2} \leq 1
$$

261 Where Qobs is the observed variable, Qsim is the model simulated output, Qobs is the

262 mean of the observation and Q $\overline{s i m}$ is the mean of the simulated output and $\mathrm{n}$ is the total

263 number of observations.

\section{B. Nash Sutcliff efficiency, NSE}

$$
N S E=1-\frac{\sum_{i=1}^{n}(\text { Qobs }-Q \operatorname{sim})^{2}}{\sum_{i=1}^{n}(\text { Qobs }-Q \overline{o b s})^{2}} ;-\infty \leq N S E \leq 1
$$

$267 \quad P B I A S=100 *\left(\frac{\sum_{i=1}^{n} Q o b s-\sum_{i=1}^{n} Q \operatorname{sim}}{\sum_{i=1}^{n} Q o b s}\right)$

268 The use of deterministic approach that results in a single set of parameters as best

269 simulation is an outdated approach in calibration as it doesn't recognize the errors and

270 uncertainties in the modelling works. Consequently, any model calibration must include 
271 the analysis of the uncertainty with propagations of parameter uncertainties [29] in 272 addition to the statistics $\mathrm{R}^{2}$, NSE and PBIAS.

273 Parameter uncertainty in SUFI-2 expressed as ranges accounts for all sources of

274 uncertainty from conceptual model, parameters, measured data and uncertainty in 275 driving variables [29]. Two statistics, $P$-factor and $R$-factor were used to quantify the

276 fit between the simulation result expressed as 95\% prediction uncertainty (95PPU) and

277 the observation. the degree to which all uncertainties are accounted for is designated by $278 P$-factor whereas, $R$-factor is the average thickness of the 95PPU envelop (30). For $P$ -

279 factor, the value of greater than $70 \%$ and $R$-factor of around 1 could be acceptable for 280 stream flow whereas, smaller value of $P$-factor and a larger value of $R$-factor could be 281 acceptable for sediment.

\section{3. Result and Discussion}

\subsection{Sensitivity Analysis, Calibration and Validation}

284 The relative sensitivity analysis for streamflow and sediment were carried out on the 285 monthly time-scale at subbasin 11 where the gauging station is located. The parameter 286 sensitivity and rankings with the significance of the relative sensitivity are determined 287 using t-stat and $p$-value. The lower $p$-stat and larger absolute t-stat value indicate the 288 most significant parameter. Using the $p$-value and t-stat, Global sensitivity using Latin 289 hypercube 'one-at-a-time' regression system was used to evaluate the relative 290 sensitivity. The sensitive streamflow and sediment in Toba watershed are described in 291 Table 3. From Table 3, top four most sensitive streamflow parameters were SCS curve 292 number (CN2), Deep aquifer percolation fraction (RCHRG_DP), saturated hydraulic 
294 The most sensitive parameters for sediment parameters are management support

295 practice factor(USLE_P), Channel cover factor (CH_COV2), Linear factor for channel

296 sediment routing (SPCON), Channel erodibility factor $(\mathrm{CH}$ _COV1) and Exponential

297 factor for sediment routing (SPEXP). These are also reported by similar studies in

298 Upper Blue Nile River Basin Ayele et al. [31] and Lemma et al.[12]. The sensitive

299 parameters were calibrated with the recommended ranges and the fitted value shown in

300 Table 3 were used to compute the amount of sediment yield from Toba watershed.

301 Table 3. List of parameters used for streamflow and sediment calibration with the

302 parameter ranges, fitted values and sensitivity ranks using SUFI-2.

\begin{tabular}{|c|c|c|c|c|c|}
\hline & Parameter & Description & Range & Fitted value & Rank \\
\hline \multirow{8}{*}{ 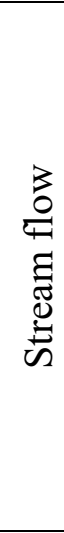 } & 1: R CN2.mgt & SCS curve number & $\pm 25 \%$ & $-10 \%$ & 1 \\
\hline & 2:V RCHRG DP.gw & Deep aquifer percolation fraction & $0-1$ & 0.063 & 2 \\
\hline & 11: $\bar{R}$ SOL_K(..).sol & Saturated hydraulic conductivity & $\pm 25 \%$ & $8.02 \%$ & 3 \\
\hline & 4: A_GW_DELAY.gw & Groundwater delay & \pm 10 & -8.43 & 4 \\
\hline & 5:A_GWQMN.gw & $\begin{array}{l}\text { Treshold depth of water in the } \\
\text { shallow aquifer required for } \\
\text { return flow to occur (mm) }\end{array}$ & $0-5000$ & 822 & 5 \\
\hline & 6:A_GW_REVAP.gw & Groundwater "revap" coefficient & \pm 0.036 & 0.0096 & 6 \\
\hline & 8: V__CH_K2.rte & $\begin{array}{l}\text { Effective hydraulic conductivity } \\
\text { in main channel alluvium }\end{array}$ & $5-130$ & 15.42 & 7 \\
\hline & 3:V_ALPHA_BF.gw & Baseflow alpha factor (days) & $0-1$ & 0.94 & 8 \\
\hline \multirow{5}{*}{ 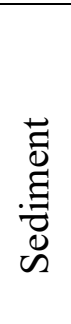 } & 19: V__USLE_P.mgt & USLE support practice factor & $0-1$ & 0.50 & 1 \\
\hline & 23: R_- & Channel cover factor & $0.001-1$ & 0.205 & 2 \\
\hline & 21: V__SPCON.bsn & $\begin{array}{l}\text { Linear factor for channel } \\
\text { sediment routing }\end{array}$ & $0.0001-0.01$ & 0.0036 & 3 \\
\hline & 22: R_CH_COV1.rte & Channel erodibility factor & $0.01-0.6$ & 0.353 & 4 \\
\hline & 20: V__SPEXP.bsn & $\begin{array}{l}\text { Exponential factor for sediment } \\
\text { routing }\end{array}$ & $1-2$ & 0.653 & 5 \\
\hline
\end{tabular}

303 Monthly streamflow and sediment datasets from 2000 to 2006 were used for model

304 calibration and 2007 to 2012 were used for model validations. The SWAT model

305 performance is considered to be acceptable for streamflow and sediment load

306 simulation on the bases of $\mathrm{R}^{2}$ and NSE $>0.5$ and PBIAS $\leq \pm 55 \%$ for sediment load and 
PBIAS $\leq \pm 25 \%$ for streamflow for a monthly time step evaluation [31,32]. Accordingly,

308 estimation of streamflow and sediment load showed satisfactory performance both in

309 calibration and validation periods. However, there is relatively lower statistical measures during the validation process. The statistical performance for streamflow and

311 sediment load are summarized in Table 4. The lower statistical measures for sediment calibration and validation could be related to the quality and scarcity of observed data,

313 parameters, streamflow process and model prediction uncertainty. The negative PBIAS

314 value during calibration and validation showed that the model slightly overestimated

315 the predicted streamflow and the positive PBIAS during validation of sediment data 316 showed under estimation.

317 To determine the degree of uncertainty and goodness of fit and the model strength, $p$ 318 factor and $R$-factor and 95PPU calculated at the $2.5 \%$ and $97.5 \%$ levels of cumulative 319 distribution. The result showed that, $76 \%$ and $58 \%$ of the measured streamflow are 320 bracketed by the 95PPU whereas, $R$-factor has a reasonable value of 0.87 and 1.01 321 during calibration and validation respectively. For sediment yield, $38 \%$ and $42 \%$ of the 322 observed data was bracketed by the 95PPU and the $R$-factor was 0.56 and 0.81 . 323 compared to streamflow, higher level of uncertainty $(38 \%)$ was reported during 324 calibration. In general, the model performance in Toba watershed have shown higher 325 superiority during validation and the results are comparable with studies in highlands 326 of Ethiopia [12,31].

327 Table 4. Monthly streamflow and sediment calibration (2000-2006) and validation 328 329 (2007-2012)

\begin{tabular}{cccccccc}
\hline & Process & p-factor & r-factor & $\mathbf{R}^{\mathbf{2}}$ & NSE & PBIAS & RSR \\
\hline \multirow{2}{*}{ Streamflow } & Calibration & 0.76 & 0.87 & 0.89 & 0.89 & -5.8 & 0.34 \\
\cline { 2 - 8 } & Validation & 0.58 & 1.01 & 0.71 & 0.52 & -22.5 & 0.69 \\
\hline
\end{tabular}




\begin{tabular}{cccccccc}
\hline \multirow{2}{*}{ Sediment } & Calibration & 0.38 & 0.56 & 0.67 & 0.66 & -8.4 & 0.58 \\
\cline { 2 - 8 } & Validation & 0.42 & 0.81 & 0.65 & 0.64 & 9.8 & 0.72 \\
\hline
\end{tabular}

330 Graphical analysis of streamflow simulation showed that, the model predictions have

331 shown both over estimation and under estimation during calibration and validation

332 (Figure 4). However, the general prediction of the model is good enough to simulate

333 the streamflow except the peak flow in most of the calibration and validation years.

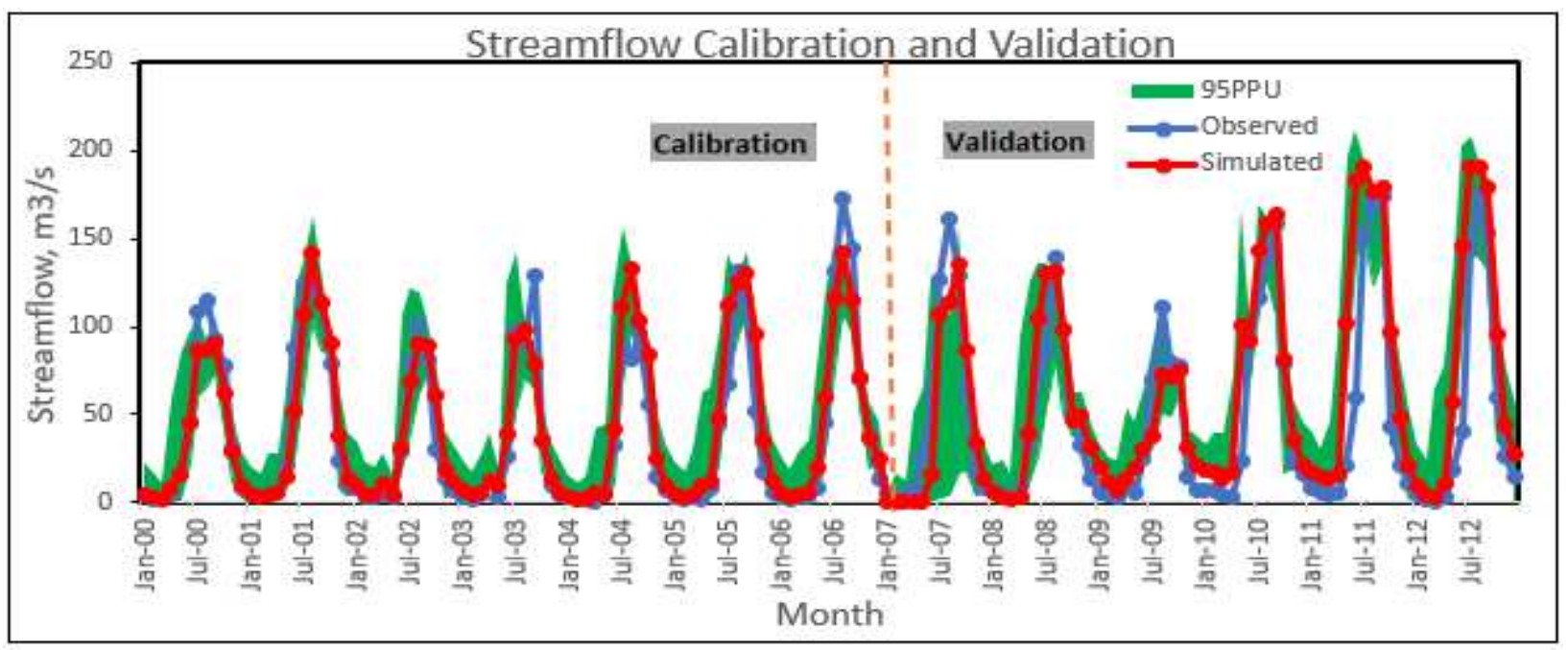

335 Figure 4. Observed and simulated streamflow calibration and validation

336 The graphical analysis of observed and the predicted sediment yield indicated that, the

337 model has shown both overestimation and underestimation during calibration and

338 underestimated sediment yield during validation (Figure 5). SWAT model was unable

339 to predict the peak sediment yield throughout the years of validation period and in some

340 years of calibration period. However, the model is able to properly simulate the rising

341 and falling limb in both cases. 


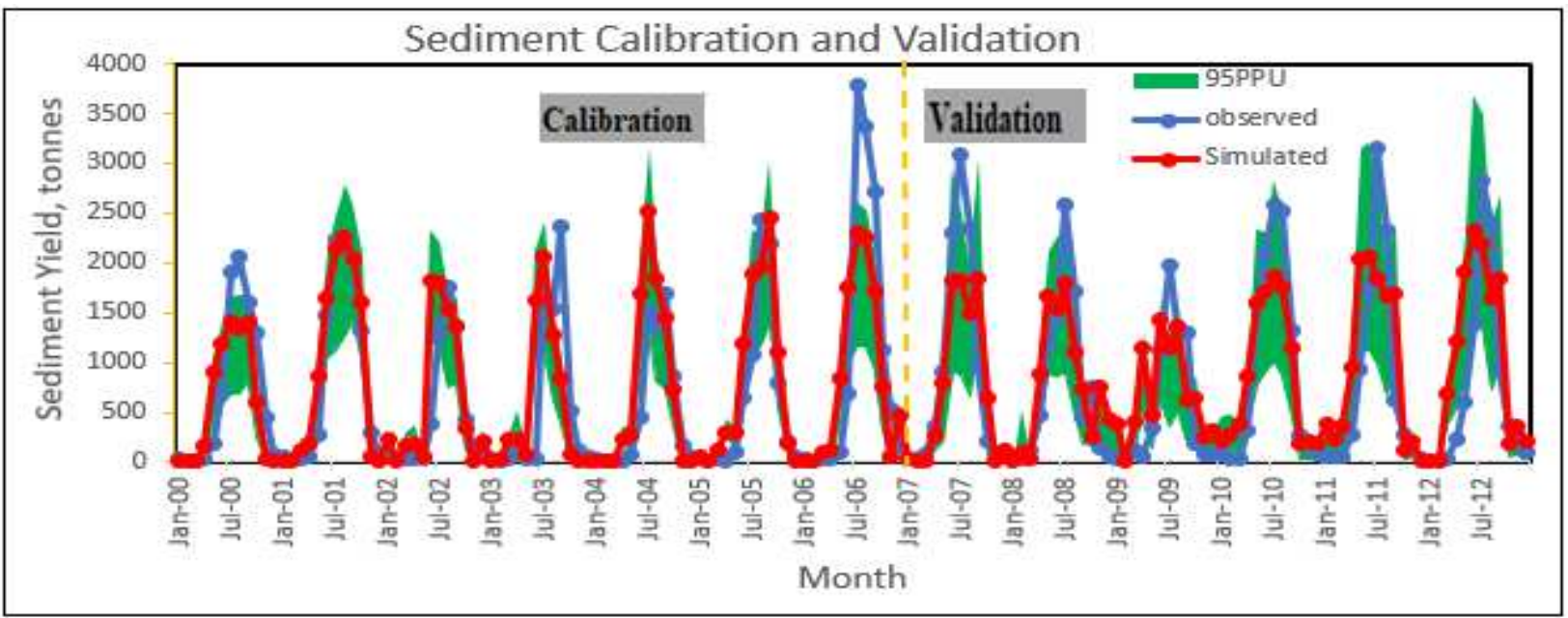

343 Figure 5. Observed and simulated sediment yield calibration and validation

\subsection{Prioritizations of Toba watershed to sediment yields}

345 Soil erosion by water has become the responsible factor for the degradation of the fertile

346 top soil from agricultural lands. This is a great challenge for agricultural productivity

347 in highland parts of Ethiopia where agriculture is the dominant activity of the

348 community. Toba watershed is one of the highland watersheds where soil erosion has

349 become the challenging problem for agricultural activity. The annual sediment yield in

350 the watershed ranges from $0.09 \mathrm{t} \mathrm{ha}^{-1} \mathrm{yr}^{-1}$ to $44.8 \mathrm{t} \mathrm{ha}^{-1} \mathrm{yr}^{-1}$ with an average sediment

351 yield of $22.7 \mathrm{tha}^{-1} \mathrm{yr}^{-1}$. The annual SY of the watershed was classified into six severity

352 classes: very low $\left(0-5 \mathrm{tha}^{-1} \mathrm{yr}^{-1}\right)$, low $\left(5-10 \mathrm{t} \mathrm{ha}^{-1} \mathrm{yr}^{-1}\right)$, moderate $\left(10-18 \mathrm{tha}^{-1} \mathrm{yr}^{-1}\right)$,

353 high (18-30 tha $\left.\mathrm{tr}^{-1} \mathrm{yr}^{-1}\right)$, very high $\left(30-40 \mathrm{tha}^{-1} \mathrm{yr}^{-1}\right)$ and severe $\left(>40 \mathrm{t} \mathrm{ha}^{-1} \mathrm{yr}^{-1}\right)($ Table

354 5). The very low and low class represents the level of erosion was less than the rate of

355 soil formation very high and severe classes showed that the SY is higher than the 356 average SY.

Table 5. Annual average SY, severity classes and area of contribution

\begin{tabular}{|c|c|c|c|}
\hline SY- $\mathrm{t} \mathrm{ha}^{-1} \mathrm{yr}^{-1}$ & Area, ha & Area, \% & Severity \\
\hline
\end{tabular}




\begin{tabular}{|l|l|l|l|}
\hline $0-5$ & 9481.14 & 5.2 & Very Low \\
\hline $5 \_11$ & 5434.29 & 3.0 & Low \\
\hline $11-18$ & 34472.5 & 18.9 & Moderate \\
\hline $18-30$ & 83835.0 & 45.9 & High \\
\hline $30-40$ & 37652.2 & 20.6 & Very high \\
\hline$>40$ & 11960.4 & 6.5 & Severe \\
\hline
\end{tabular}

358 The spatial distribution of the sediment sources shows that, very low and low SY $(<11$

$359 \mathrm{t} \mathrm{ha}^{-1} \mathrm{yr}^{-1}$ ) in the watershed was generated from sub-basin 18, 19 and 14 (Figure 6).

360 These sub-basins accounted about $8.2 \%$ of the total watershed and they are dominantly

361 covered by forest land. The highest contributor of SY $\left(>40 \mathrm{t} \mathrm{ha}^{-1} \mathrm{yr}^{-1)}\right)$ are sub-basin 1

362 and 2 located in the highland areas, northern part of the watershed. These sub-basins

363 are characterized by cultivated crop. This shows that human activities in the higher

364 slopes were the main driving factor of SY. In general, areas that have good vegetation

365 cover around the middle parts of the watershed are characterized by lower SY and

366 sloping agricultural lands are the dominant sources of higher SY. The study indicated

367 that SY is more sensitive to land use classes revealing areas under minimal disturbances

368 are not a significant source of erosion and areas under extensive agriculture are the

369 sources of high erosion. 


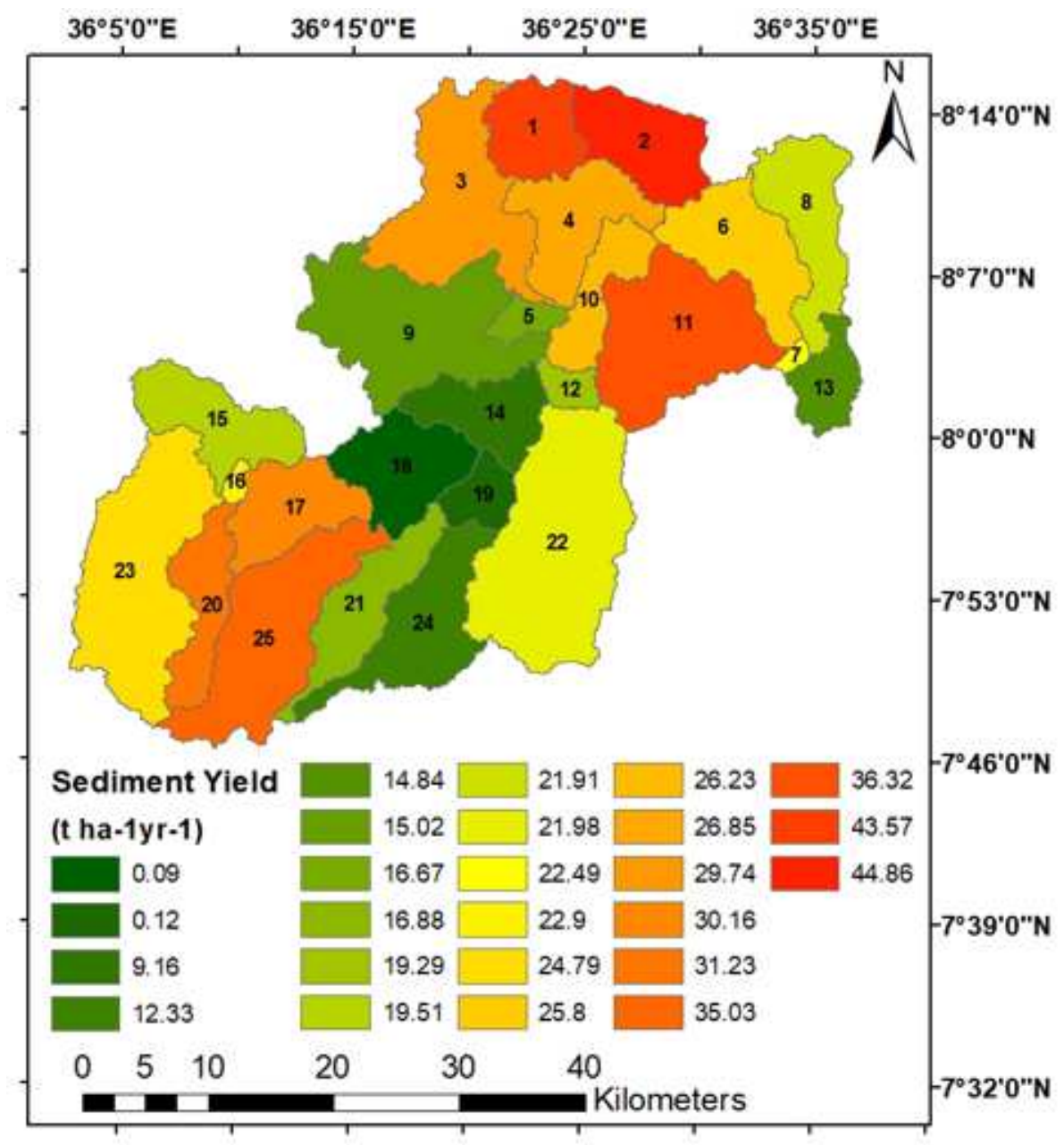

Figure 6. Spatial distribution of sediment yields in Toba watershed

372 The estimated annual average rate of SY in Toba watershed was $22.7 \mathrm{tha}^{-1} \mathrm{yr}^{-1}$. This

373 was higher than the tolerable soil loss $\left(2-18 \mathrm{t} \mathrm{ha}^{-1} \mathrm{yr}^{-1}\right)$ from agricultural lands in

374 Ethiopia as it was suggested by Hurni [33]. However, the annual average SY predicted

375 in Toba watershed is less than the rates of average soil erosion reported in different

376 parts of Blue Nile Basin. Ayele et al. [31] in Koga catchment, a tributary to Gilgel Abay

377 (24.3 $\left.\mathrm{tha}^{-1} \mathrm{yr}^{-1}\right)$, Gashaw et al. [34] in Geleda watershed (23.7 $\left.\mathrm{tha}^{-1} \mathrm{yr}^{-1}\right)$, Lemma et al.

378 [12] in Lake Tana Basin (32 $\left.\mathrm{t} \mathrm{ha}^{-1} \mathrm{yr}^{-1}\right)$, Yesuph \& Dagnew [35] in the Beshillo 379 catchment $\left(35 \mathrm{t} \mathrm{ha}^{-1} \mathrm{yr}^{-1}\right)$ and Dibaba et al. [17] in the Finchaa catchment $\left(36.47 \mathrm{tha}^{-1}\right.$ $\left.380 \mathrm{yr}^{-1}\right)$. The variations of the soil loss in different parts of the Blue Nile reveals that, SY 
varies with difference in agroecology and biophysical environments. Relatively, the

382 lower average soil loss in Toba watershed could be attributed to the good vegetation 383 cover (forest was the second dominant land use class) compared to the other areas. Most 384 of the soil loss estimates inn Ethiopia are based on RUSLE model. Although the model 385 is simple and can be developed with small input parameters in areas like Ethiopia where 386 data is limited, the outputs of RUSLE model is sensitive to the input parameters. In 387 RUSLE model there is no option to identify the most sensitive parameters like the other 388 models.

\section{$389 \quad 3.3$ Evaluation of Best management Practices}

390 Usually, it is important to establish threshold value between tolerable and intolerable 391 level of soil erosion to minimize the risks of soil erosion. The rate of soil loss considered 392 as tolerable based on maintenance of crop production was reported from 1 to $11 \mathrm{tha} \mathrm{ha}^{-1}$ $393 \mathrm{yr}^{-1}[36]$. According to FAO [36], SY from $8.2 \%$ of the watershed is considered as a

394 tolerable rate of erosion. In Ethiopia, the tolerable rate of soil loss in different agro395 ecological conditions were reported from 2 to $18 \mathrm{t} \mathrm{ha}^{-1} \mathrm{yr}^{-1}$ [33]. In this study, sub396 basins that generates SY more than $18 \mathrm{t} \mathrm{ha}^{-1} \mathrm{yr}^{-1}$ which accounts for $72.9 \%$ were 397 considered for the BMP scenario analysis. From the total 25 sub basins, only 8 sub398 basins generate the tolerable soil loss and the remining 17 sub-basins require urgent 399 actions for management.

400 The summary of implementing the individual BMPs and their combination in Toba 401 watershed was summarized in Table 6. The lowest SY reduction was reported as $36.1 \%$ 402 during the implementations of filter strip (FS) whereas the highest reduction was 403 reported as $80.5 \%$ by the simulation of vegetative strip (VS) followed by soil/stone 
404 bund (SB). Application of SB on steep slopes and reforestation of the hilly areas 405 reported SY reduction by $69.3 \%$ and $47.5 \%$ respectively. However, implementing the 406 combinations of the BMP scenarios improved SY reduction better. The highest 407 reduction in SY was attained by the combination of R and VS followed by SB and VS. 408 This finding suggests a reasonable reduction of SY requires implementation of 409 appropriate combinations of BMPs. Improved reduction of SY by combining the BMPs 410 is also reported by similar studies [13].

411 Table 6. estimated SY reduction due to BMPs compared to the baseline scenario

\begin{tabular}{|l|l|}
\hline Scenarios & Percentage of change in SY, \% \\
\hline FS & 36.1 \\
\hline SB & 69.3 \\
\hline VS & 80.5 \\
\hline R & 47.5 \\
\hline R+SB & 77 \\
\hline R+VS & 87.8 \\
\hline SB+VS & 83.7 \\
\hline
\end{tabular}

412 Although the application of all BMPs have shown reasonable reduction of SY, the 413 simulation of all BMPs revealed considerable spatial variability (Figure 7). The 414 application of the combination of the BMPs, SB and VS reduced SY below the tolerable 415 soil loss over the entire critical areas of the watershed. Whereas, the application of FS 416 and $\mathrm{R}$ alone can note alleviate the risk of soil erosion fully from the whole watershed 417 with in the tolerable limit of the soil loss. Particularly, 7 sub-basins under FS and two 418 sub-basins under R still generates SY beyond the limit of tolerable soil loss (Figure 7). 

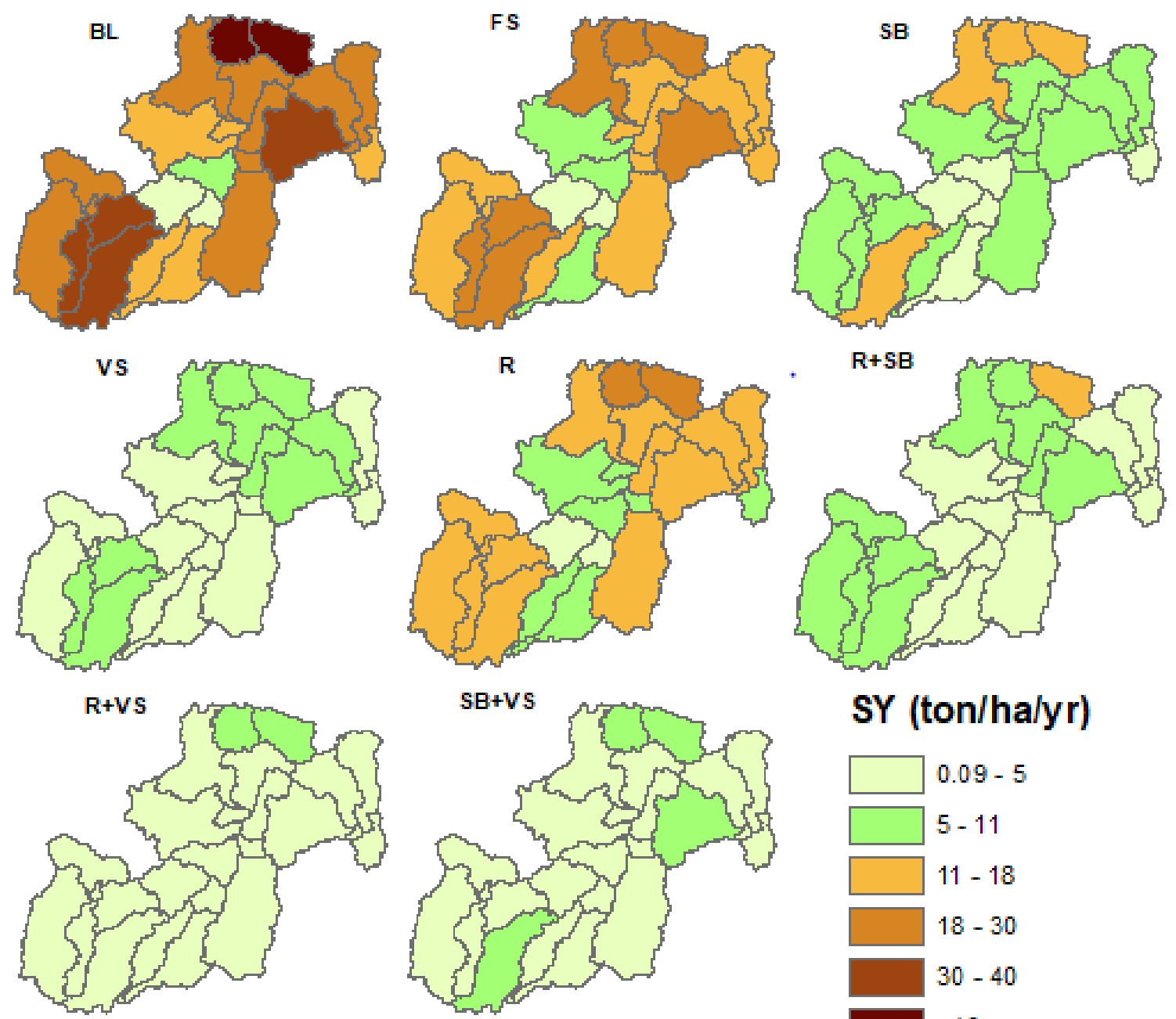

SY (ton/ha/yr)

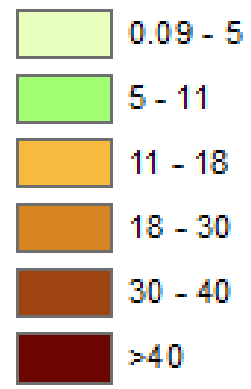

421 Figure 7. impacts of BMPS on the reduction in sediment yield

\subsection{Management and policy implications}

423 Considering different alternatives for investigating the possible soil and water

424 management practices is one of the imaginable outcomes of the study for decision

425 makers. The concept of the management practices is that development and management

426 of watershed resources should achieve sustainable production without causing 427 deterioration to the resource base or causing any ecological imbalances. In this regard, 428 an integrative systemic approach that helps to reverse the land degradation through 
water erosion by regulation of hydrological and ecological processes is required as

430 poorly planned management practice could result in complete failure.

431 The limited and slower response to the multifaceted issues of communities and the need

432 to integration and comprehensive action are yet exacerbating the environmental

433 problems. There are some efforts towards natural resources management like integrated

434 water and soil conservation practices. However, poor collaboration and coordination in

435 designing and implementing comprehensive and integrated development interventions

436 that can support sustainable development in a fullest sense are still remaining

437 bottlenecks which need attention and focus from all concerned actors. In most cases,

438 the development interventions in our country, the study area in particular are

439 overlooking to make an in-depth analysis and understanding about the environment-

440 population nexus. Consequently, the severity of the environmental problem related to

441 soil erosion currently emerging in the watershed and the region at large is caused by the

442 uncontrolled population-environment nexus outcomes. The peculiar characteristic of

443 the population of the Oromia region where the study is located is that very limited size

444 of land holding to the farmers is the cause for cultivation of steep slope which has

445 become a source of erosion and sediment loss in the watershed as shown in sub basin 1

446 and 2 in Figure 6. The emphasis of the local government on expanding agriculture lands

447 every year so as to ensure food security of the area and also create job opportunity for

448 youths could be the main reason for uncontrolled extensive agricultural expansion.

449 The major problem of management in Ethiopia is interventions were done without prior

450 investigations and the need of local population for conservation. Moreover, there is no

451 sort of organizational structure to the grass root level, for instance watershed committee 
452 for watershed conservation and most of the activities were done through mass

453 mobilization. The relevance of policy and program tools for land conservation through

454 mobilization however depends on whether or not the farm households are convinced of

455 the need to adopt conservation investments. On the other hand, implementations of

456 various management practices are highly affected by the agro-ecological variations,

457 technology used by the community and institutional supports, research supports and

458 public awareness [10,37]. Most of the factors are still the triggering factors of the

459 natural resources management failures. In this regard, management practices require

460 the need for engagement in a long-term practice regardless of the underlying

461 biophysical endowments and environment.

462 Further, local knowledge of water management is not always adequate. For example;

463 in some cases, there has been over drainage, leading to the resources being abandoned

464 from cultivation. This sort of problem may sometimes be the result of a lack of 465 adaptation of local knowledge to specific sites or changes in environmental conditions 466 to which this knowledge is applied. In other cases, it may be the result of incomplete 467 transfer of knowledge from community to community.

468 This provides an opportunity to achieve consistency in policies and actions at all levels 469 and scopes, from local to global. Collaborative planning and actions at the landscape 470 scale are an important foundation for maximizing cross departmental synergy. Effective 471 inter-sectoral coordination requires stakeholders to share evidence, information, and 472 best practices; and coordinate the planning, implementation, and monitoring processes 473 are harmonized at the landscape level. Integrated landscape or catchment management 474 ensures that by managing the underpinning natural resource base and ecosystem 
services in a coordinated way, societal needs can be met in the short and long term.

476 Therefore, the application of best management practices stated in chapter 3 for

477 enhancing the socio-ecological resilience of Toba watershed can be aligned with the

478 integrated landscape approach of addressing multiple goals of sustainable development.

479 The implementations of best management practice should consider the coordinated 480 development and management of land and water with the broader upstream and 481 downstream interests. Three important pillars have to be developed: developing proper 482 policies, strategies and legislation with proper finance and incentive structures, forming 483 a framework for institutions through which policies can be implemented and set up 484 management systems for the institutions to do their job.

485 Strategic Goal 1: Enhancing Ecological Resilience of the catchment through 486 improving management of biophysical resources (mainly soil and vegetation) and also 487 through restoration of degraded ecosystems and sites.

488 Strategic Goal 2: Improving socio-economic development and community's 489 livelihood in the target catchment through promoting small-scale and community 490 owned green enterprises for enhancing socio-economic resilience. Therefore, 491 intervention packages that can be linked to this strategic goal of enhancing socio492 economic resilience should logically be targeting on improving and/or modernizing the 493 agricultural production system through intensification, among others. An important 494 consideration of these interventions is that they have to contribute to the realization of 495 eco-friendly or climate-smart agricultural production systems.

496 4. Conclusion

497 Soil erosion by water has become a challenge facing agricultural production in 
agricultural watersheds. The increasing risks of soil erosion and related environmental

499 problems have driven the need for research to address sustainable land and water

500 resources management. This study attempted to examine the soil erosion status of Toba

501 watershed and identify hotspot areas for effective watershed management interventions

502 to reduce the risk of sediment generation. Considering different alternatives to

503 investigate the possible soil and water management practices is one of the conceivable

504 outcomes of the study for decision policy.

505 The estimated annual sediment yield varies from $0.09 \mathrm{t} \mathrm{ha}^{-1} \mathrm{yr}^{-1}$ to $44.8 \mathrm{t} \mathrm{ha}^{-1} \mathrm{yr}^{-1}$ with

506 an average sediment yield of $22.7 \mathrm{t} \mathrm{ha}^{-1} \mathrm{yr}^{-1}$. The highest SY was contributed by the

507 steep farmland. The severity of erosion at the very low, low and moderate severity

508 levels covering $27.1 \%$ of the watershed area was within the tolerable ranges of soil

509 erosion in Ethiopia (2 to $18 \mathrm{t} \mathrm{ha}^{-1} \mathrm{yr}^{-1}$ ). Seventeen sub-basins, which represent about

$51072.9 \%$ of the watershed area, have been identified as critical areas that require

511 implementation of proper measures.

512 Regardless of the considerable SY by all scenarios, the simulation of the individual

513 BMPs in reducing SY over Toba watershed has varied appreciably. The application of

514 certain scenarios (FS and R) cannot reduce the risk of soil erosion below the tolerable

515 limit of the soil loss. However, the combination of the scenario is more pronounced and

516 desirable in SY reduction. Therefore, this finding suggests that a reasonable reduction

517 in SY requires the implementation of an appropriate combinations of BMPs.

518 Overall, the study demonstrated how prioritization of erosion hotspot areas can be used

519 to aid systematic watershed planning through the use of modelling, SWAT. Coordinated

520 development and management of land and water with the broader upstream and 
521 downstream interests could help to achieve better implementation of best management 522 practice. Therefore, this study recommends, creating awareness of the risk of soil 523 degradation in order to persuade and ensure the long-term engagement of the 524 community and stake holders in management activities.

\section{$525 \quad$ Declarations}

\section{Competing Interest}

527 The authors declare that they have no competing interests.

\section{Funding}

529 This research received no external funding.

\section{$530 \quad$ Author Contributions}

531 Wakjira T Dibaba have developed the concept of the study, methodology, and formal

532 analysis. Dessalegn G Ebsa conducted field works, investigation. Both authors involved 533 in writing review and editing the manuscript. All authors have read and agreed to the

534 published version of the manuscript.

\section{Acknowledgments}

536 we would like to thank the Ministry of Water, Irrigation and Electricity (MoWIE) and

537 National Meteorological Agency for providing the streamflow, sediment data and 538 climate data.

\section{$539 \quad$ References}

540 1. Schmidt E, Tadesse F. The impact of sustainable land management on household crop production in the Blue Nile Basin, Ethiopia. L Degrad Dev. 2019;30:777- 
543 2. Worku GB, Mekonnen A. Investments in Land Conservation in the Ethiopian Highlands: A Household Plot-level Analysis of the Roles of Poverty, Tenure Security, and Market Incentives. Int J Econ Financ. 2012;4(6):32-50.

546 3. Haregeweyn N, Tsunekawa A, Poesen J, Tsubo M, Meshesha DT, Fenta AA, et al. Comprehensive assessment of soil erosion risk for better land use planning in http://dx.doi.org/10.1016/j.scitotenv.2016.09.019

551 4. Dibaba WT, Demissie TA, Miegel K. Drivers and Implications of Land Use/Land Cover Dynamics in Finchaa Catchment, Northwestern Ethiopia. Land. 2020;9(4):1-22. 
559 6. Ebabu K, Tsunekawa A, Haregeweyn N, Adgo E, Meshesha DT, Aklog D, et al. Effects of land use and sustainable land management practices on runoff and soil

from:

5647 CGIAR RP on W and E. Healthy soils for productive and resilient agricultural landscapes. Colombo, Sri Lanka: CGIAR Research Program on Water, Land and Ecosystems (WLE). 12p. (WLE Towards Sustainable Intensification: Insights and Solutions Brief 2); 2017.

8. Aga AO, Chane B, Melesse AM. Soil erosion modelling and risk assessment in data Scarce Rift Valley Lake Regions, Ethiopia. Water. 2018;10(11). Development,Addis Abeba, Ethiopia; 2005. sustainable land management practices by rural households in Tigrai region, 
576 11. Ricci GF, De Girolamo AM, Abdelwahab OM., Gentile F. Identifying sediment source areas in a Mediterranean watershed using the SWAT model. L Degrad Dev. 2018;29:1233-1248.

12. Lemma H, Frankl A, Griensven A van, Poesen J, Adgo E, Nyssen J. Identifying erosion hotspots in Lake Tana Basin from a multisite Soil and Water Assessment Tool validation: Opportunity for land managers. L Degrad Dev. 2019;30:144967.

13. Uniyal B, Jha MK, Verma AK, Anebagilu PK. Identification of critical areas and evaluation of best management practices using SWAT for sustainable watershed management. Sci Total Environ [Internet]. 2020;744:140737. Available from:

587 14. Haregeweyn N, Tsunekawa A, Nyssen J, Poesen J, Tsubo M, Meshesha DT, et 588 589 2015;39(6):750-74.

590 15. Tefera B, Sterk G. Land management, erosion problems and soil and water conservation in Fincha'a watershed, western Ethiopia. Land use policy. 2010;27:1027-37. 
16. Sultan D, Tsunekawa A, Haregeweyn N, Adgo E, Tsubo M, Meshesha DT, et al. Analyzing the runoff response to soil and water conservation measures in a tropical humid Ethiopian highland. Phys Geogr. 2017;38(5):423-447.

17. Dibaba WT, Demissie TA, Miegel K. Prioritization of Sub-Watersheds to Sediment Yield and Evaluation of Best Management Practices in Highland Ethiopia, Finchaa Catchment. Land. 2021;10(650).

18. Pandey S, Kumar P, Zlatic M, Nautiyal R, Panwar VP. Recent advances in assessment of soil erosion vulnerability in a watershed. Int Soil Water Conserv

601

602 https://doi.org/10.1016/j.iswcr.2021.03.001

603

19. Arabi M, Frankenberger JR, Engel BA, Arnold JG. Representation of 604 agricultural conservation practices with SWAT. Hydrol Process. 2007;22:3042-

605 55.

606

20. Tufa FG, Sime CH. Stream flow modeling using SWAT model and the model 607 performance evaluation in Toba sub-watershed, Ethiopia. Model Earth Syst 608 Environ [Internet]. 2020;7(0123456789). Available from: 
610 21. Arnold JG, Srinivasan R, Muttiah RS, Williams JR. Large Area Hydrologic Assoc. 1998;34(1):73-89.

613

22. Gathagu JN, Mourad KA, Sang J. Effectiveness of Contour Farming and Filter Strips on Ecosystem Services. Water. 2018;10:1-14.

615 23. Neitsch SL, Arnold JG, Kiniry JR, Williams JR. Soil \& Water Assessment Tool Theoretical Documentation Version 2009. Technical Report No.406; Texas Water Resources Institute, College Station,Tx,USA; 2011.

618

24. Neitsch S, Arnold J, Kiniry J, Williams J. Soil and Water Assessment Tool Theoretical Documentation. Grassland, Soil and Water Research Laboratory, Agricultural Research Service, Temple, TX; 2005.

621 25. Choto M, Fetene A. Impacts of land use/land cover change on stream flow and sediment yield of Gojeb watershed, Omo- Gibe basin, Ethiopia. Remote Sens Appl Soc Environ [Internet]. 2019; Available from: https://doi.org/10.1016/j.rsase.2019.01.003

26. Abdelwahab OMM, Bingner RL, Milillo F, Gentile F. Effectiveness of alternative management scenarios on the sediment load in a Mediterranean 
agricultural watershed. J Agric Eng. 2014;XLV:430:125-36.

27. Hurni H, Berhe W, Chadhokar P, Daniel D, Gete Z, Grunder M, et al. Soil and Water_Conservation in Ethiopia: Guidelines for Development Agents. Second rev. Bern, Switzerland: Centre for Development and Environment (CDE), University of Bern, with Bern Open Publishing (BOP).; 2016. 134 p.

28. Gebremichael D, Nyssen J, Poesen J, Deckers J, Haile M, Govers G, et al. Effectiveness of stone bunds in controlling soil erosion on cropland in the Tigray Highlands, northern Ethiopia. Soil Use Manag. 2005;21:287-97.

29. Abbaspour KC. SWAT-CUP: SWAT Calibration and Uncertainty Programs- A User Manual. Eawag: Dübendorf, Switzerland; 2015.

637 30. Abbaspour KC, Vaghefi SA, Srinivasan R. A guideline for successful calibration and uncertainty analysis for soil and water assessment: A review of papers from the 2016 international SWAT conference. Water. 2017;10(6):1-18.

640 31. Ayele GT, Teshale EZ, Yu B, Rutherfurd ID, Jeong J. Streamflow and Sediment Yield Prediction for Watershed Prioritization in the Upper Blue Nile River Basin, Ethiopia. Water. 2017;9(782):1-28.

643 32. Moriasi DN, Arnold JG, Liew MW Van, Bingner RL, Harmel RD, Veith TL. 
644 Model evaluation guidelines for systematic quantification of accuracy in

645 watershed simulation. Am Soc Agric Biol Eng. 2007;50(3):885-900.

646 33. Hurni H. Erosion-productivity-conservation systems in Ethiopia. In:

647 Proceedings of the 4th International Conference on Soil Conservation,. Maracay

$648 \quad$ Venezuela; 1985. p. 654-674.

649 34. Gashaw T, Tulu T, Argaw M. Erosion risk assessment for prioritization of 650 conservation measures in Geleda watershed, Blue Nile basin, Ethiopia. Environ

$651 \quad$ Syst Res. 2017;6(1):1-14.

652 35. Yesuph AY, Dagnew AB. Soil erosion mapping and severity analysis based on 653 RUSLE model and local perception in the Beshillo Catchment of the Blue Nile Basin, Ethiopia. Environ Syst Res. 2019;8(17):1-21.

655

36. FAO. Soil erosion: the greatest challenge to sustainable soil management. Rome;

656 2019.

657 37. Miheretu BA, Yimer AA. Determinants of farmers ' adoption of land 658 management practices in Gelana sub- watershed of Northern highlands of Ethiopia. Ecol Process. 2017;6(19):1-11. 